\title{
THE IMPACT OF SOCIO-EMOTIONAL INTELLIGENCE ON ACADEMIC PERFORMANCE
}

\author{
Jamshid Ali Turi**, Muhammad Faizal A. Ghani $^{\text {b }}$, Yasir Javid ${ }^{\mathrm{c}}$, Dr. Shaharyar Sorooshian ${ }^{\mathrm{d}}$ \\ $\mathrm{a}^{*}$ University Malaysia Pahang \\ 26600 Pekan, Pahang, Malaysia, Jamshidturi@gmail.com \\ ${ }^{\mathrm{b}}$ University of Malaya \\ 50603 Kuala Lumpur, Malaysia, mdfaizal@ump.edu.my \\ ${ }^{\mathrm{c}}$ Abbottabad Campus \\ , yjaved@gmail.com \\ ${ }^{\mathrm{d}}$ University Malaysia Pahang \\ 26600 Pekan, Pahang, Malaysia, sorooshian@ump.edu.my
}

\begin{abstract}
The study was designed to check the impact of socio-emotional intelligence on academic performance of the university students. The target population was BS, MS and PhD students of the COMSATS institute for information technology. Self-administered questionnaire based survey method was adopted using Bar On EQ-I questionnaire for data collection based on non-random sampling (Convenient) sampling method. Results indicate positive correlation between socioemotional intelligence and academic performance and the results recommend penetration of socio-emotional intelligence practices in teaching learning processes for getting best possible academics objectives.
\end{abstract}

Keywords: Socio-emotional Intelligence, academic performance, Teaching-learning processes

Received: 17 June 2018 - Revised: 05 Sep 2019 - Accepted 12 Nov 2019 -Available online 30 Dec 2019

\section{INTRODUCTION}

\section{Socio-emotional Intelligence}

Emotional Intelligence has a century backed history and can be found in the work of Aristotle and other different researchers (FME, 2014; Jordan, 2014). But formally it was introduced with intensity and application in the writing of Goleman in his best-selling book "Emotional Intelligence Why It Can Matter More Than IQ" in 1995. It is defined as the ability to recognize the emotions of self and other and respond them accordingly (Mayer, Salovey, Caruso, \& Cherkasskiy, 2011). Thorndike (1920) also explained it in his social intelligence theory by stating to understand, accept and react wisely to the emotions of all human beings that may be man, woman, boy or girl (BBPSD, 2010; Blerk, 2013).
Socio-emotional intelligence and academic performance

Socio-emotional intelligence is considering as a predictor of academic performance, a prerequisite for academic performance and achievements (Nasir \& Masrur, 2010; Saeed, 2014). It develops intrinsic motivations among the student of all age, gender, color and cost for both short and long term academic achievements (Bhadouria Preeti, 2013; Nasir, 2012). It is more demanding at primary and secondary levels to develop confidence, empathy and socialization among kids (Zain \& Hassan, 2013). Similarly, in higher, technical, medical and engineering education, Emotional intelligence integration is demanded and recommended by different researchers (Riemer, 2003; Chamundeswari, 2013; Arockia \& Sangeetha, 2013). Emotional intelligence, when tested among socially 
disadvantaged and ill-mannered student, it proved it positive correlation with academic performance and also worked in behavior modification (Ghosh, 2014; Petrides, Federickson, \& Furnham, 2004). But it does not mean that EI is the single major contributes in academic. Greater variation can be seen in research studies which links EI to academic performance (Costa \& Faria, 2015; Lynch \& Simpson, 2010). Some research studies findings negate relation of EI with academic's contributions (Austina, Evansb, Goldwatera, \& Pottera, 2005). According to other research studies, EI develop personality of the learner which further enhances their academic performances (Brackett, Rivers, \& Salovey, 2011; Loise M.Ladrazo \& Barchard, 2013; Brackett, Rivers, \& Salovey, 2011). Goroshit (2014) Study concluded that EI has indirect effect on academic performance through the mediating role of self-efficacy which further increases academic performance. All these researches proved the efficacy of social and emotional intelligence with academic performance, whether its direct or indirect.

Intrapersonal skills and academic performance Intrapersonal skills focus on inner hidden skills, thoughts, strength and potentials and lead them to self-actualization phase. It helps in recognizing person's own-self, their strengths and weaknesses, moods and emotions and their impacts on others (Boud, Cohen, \& Sampson, 2006; Borah, 2013). These people are selfeager, self-aware, assertive and love to work independently. Intrapersonal skills development leads to self-construction from inside-out, helps in developing confidence and improve decision making skills. Through intrapersonal skills person control his thoughts and actions, remains motivated, calm and confident and start believe in himself, both consciously and subconsciously, which increase productivity and performance (Sambaiah, 2016; The McGraw-Hill Companies, 2010). Shabana (2013) state that with high intra-personal skills and selfawareness intrinsic motivations are created which lead to high academic performance. Beside this, it improves learning strategies, memorization and cognition abilities (Taheri, 2016). It develops self-regulation, which is the ability to develop, implement, and flexibly maintain planned behavior in order to achieve one's goals. It is also considering as an ability to control or redirect impulses and moods, its propensity to suspend judgment and think before acting. According to social cognitive theory of self-regulation, it plays the role of mediation between external influences and purposive human behaviors (Bandura, 1991).

Self-regulation in a student is consider as an important predictor and motivation for academic performance (Zumbrunn \& Tadlock, 2011) (Kitsantas, Winsler, \& Huie, 2008). In online learning, self-regulation has rendered result in good academic achievement and goalorientations (Matuga, 2009). Besides these, it is used to regulate behaviors and emotions in academic processes, which give results in good academic performance (Morrison, Ponitz, \& McClelland, 2010). It develops motivation in students, whether intrinsic or extrinsic, which is one of the most important factors in academic performance and student success and give zests, determination and excitement to reach to the heights (Singh, 2011).

Interpersonal skills and academic performance Interpersonal skills are the foundations for human relations, pave road to work with diverse people in heterogeneous environment (The McGraw-Hill Companies, 2010; Brackett, Rivers, \& Salovey, 2011). It focuses on improving Cross-cultural sensitivity and giving full satisfactory services to the demanding people. Human by its very nature is a social entity, empathetic, focus on developing better relations with peer, behave and perform well in valued, cultured and socio-emotionally charged environment. Living in friendly and supporting environment adds to positive personality development and gradually remove negative habits and behaviors from the student. Due to positive enforcements, academic performance is improved (Sambaiah, 2016). Learner remains happy, adoptable, motivated, learn to respect other's point of view, influence and some-times get influenced, solve academic and social problems in collaboration and learns leading manners (Bratton, Dodd, \& Brown, 2011; Comedis, 2014). 
One of the core areas of Interpersonal relationship is the development of social skills, which refer to getting proficiency in managing relationships and building networks. These skills lay foundations for success in academics as well as in practical life (Lynch \& Simpson, 2010) and influence mental health (Huitt \& Dawson, 2011). Social skills prepare students to use learning skills and facilitate prosocial behaviors (Comedis, 2014). Research shows that student with social skills performs better in academics (Bloom, 2007) build cognitive competences (Feitosa, Prette, \& Prette, 2012) therefore academic and social skills should be integrated in syllabus (Eleby, 2009).

General mood and academic performance

Mood is natural but unstable phenomenon, remain switch off and on from time to time. But general mood, as defined and used in EI, is general, stable, less intense phenomenon, having guiding and directing stimuli towards objectives (Hume, 2013). Mood is a plastic entity, can be changed through different stimuli like food, environment and culture (Maria A. Polak, Flet, Brookie, \& S.Conner, 2015). EI treatments and practice promote positive moods in learner, which helps in solving complex cognitive problems, has facilitating impact on memory, create confidence and smoothen learning and decision-making processes; and negative mood lead to depression and lower academic performance (Khurshid, Parveen, Yousuf, \& Chaudhry, 2015). Research shows that positive mood regulates emotions, control impulses, promote social positive engagement and have good impacts on learning activities (Gumora \& Arsenio, 2002).

Stress management and academic performance Stress is not a worthy thing to be managed, but if left uncontrolled, then it controls the beholder and makes the them worthless. Stress is a natural response to any unexpected situations in abnormal way. It differs in intensity depending upon so many internal and external stimuli. According to Shastri (2016) it is common to all students to take stress whether he is low or high achiever. If the beholder is not stronger, managed and developed, they can't response in a desired way (Academic
Skills Center, 2013). If stress is smaller in value, it improves productivity, prepares the beholder, makes him ready in advance to cope, but if it is bigger in size and complex in nature than it creates complex problems (Kranner, Minibayeva, Beckett, \& Sea, 2010). If students are provided with adequate training in coping and dealing with the stresses, they can manage their stress and in better way academic processing can occur (Mandale, 2010). Some research studies don't find any correlation between stress management strategies but many studies suggest that stress tolerance and good impulse control strategies teaching, training and treatment are provided, it construct personality of the learner, enable learners to deal with the unexpected occurring and improve academic performance if managed well in time (S, Jose, \& Valsaraj, 2015; Khurshid, Parveen, Yousuf, \& Chaudhry, 2015).

\section{Adaptability and academic performance}

Human is adoptable, flexible and responsive; adjust itself to new situations and environment. Nothing is constant in the world except the change. According to the changing environment, needs, and demands of the socioeconomic life changes and human adept or adopt itself accordingly (Oliver, 2014; Tiwari, Pandey, \& Sharma, 2010). Adoptability increases with exposures, intrapersonal and interpersonal skills. It develops creativity, increase performance, develop critical problem-solving skills, competition, and socioeconomic productivity (Holtkamp, 2014). In educational setting, it brings exploration (Miller, 2009), increase academic adjustment and performance (Nasir, 2012), promote better behavior, dealing and relationship (Collie, Holliman, \& Martin, 2016). With socioemotional intelligence training student's adoptability traits can be improved, which eventually improve learning behaviors and academic performance (Bandura, 1991; Arockia \& Sangeetha, 2013). 


\begin{tabular}{crrrrr} 
SEI & 25 & 2.44 & 4.30 & 3.326 & .34940 \\
& 5 & & & 3 & \\
Valid N & 25 & & & & \\
(list wise) & 5 & & & & \\
\hline
\end{tabular}

Conceptual Framework for the Study:

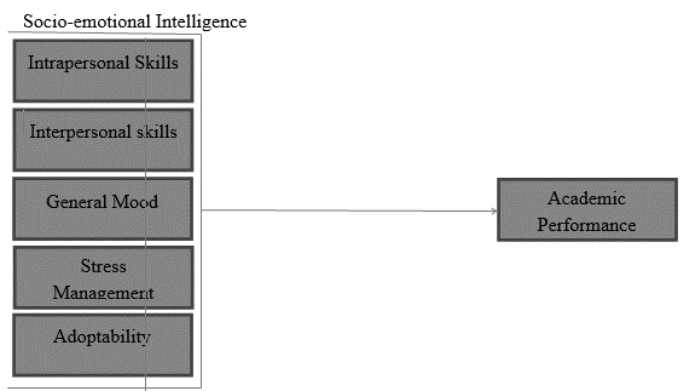

Source: (Bar-On, 2006)

\section{METHODS}

Study was quantitative in nature based on survey data using BarOn EQ (I) questionnaire. Convenient sampling technique was used because entire population was qualifying criteria for studies. 255 students from BS (131), MS (91) and $\mathrm{PhD}(33)$ programs participated in the survey among them 98 (38\%) were female and $157(62 \%)$ were male. In study efforts were made to give proper proportion to all programs and gender. Data was analyzed with 5-likert scale (strongly disagree $=1$, Agree $=2$, Neutral= 3 , Agree $=4$, Strongly Agree $=5$ ) .

Reliability of the scale was checked using Cronbach's Alpha and scale was found reliable and internally consistent in getting the answers of the questions. Reliability for Intrapersonal skills was 0.727 for 12 items, for Interpersonal 0.635 for 12 items, for General Mood 0.646 for 12 items, for Adoptability 0.675 for 12 items and for stress management 0.635 for 8 items.

Descriptive Statistics:

Table 2; Descriptive Statistics

\begin{tabular}{|c|c|c|c|c|c|}
\hline & $\mathrm{N}$ & $\begin{array}{c}\text { Minimu } \\
\mathrm{m}\end{array}$ & $\begin{array}{c}\text { Maximu } \\
\mathrm{m}\end{array}$ & $\begin{array}{c}\text { Mea } \\
\mathrm{n}\end{array}$ & $\begin{array}{c}\text { Std. } \\
\text { Deviati } \\
\text { on }\end{array}$ \\
\hline CGPA & $\begin{array}{r}25 \\
5\end{array}$ & 2.30 & 3.91 & $\begin{array}{r}3.275 \\
1\end{array}$ & .40518 \\
\hline $\begin{array}{c}\text { Intraperso } \\
\text { nal }\end{array}$ & $\begin{array}{r}25 \\
5\end{array}$ & 2.08 & 4.50 & $\begin{array}{r}3.357 \\
8\end{array}$ & .54703 \\
\hline $\begin{array}{l}\text { General } \\
\text { Mood }\end{array}$ & $\begin{array}{r}25 \\
5\end{array}$ & 2.58 & 4.83 & $\begin{array}{r}3.718 \\
0\end{array}$ & .45133 \\
\hline $\begin{array}{c}\text { Interperso } \\
\text { nal }\end{array}$ & $\begin{array}{r}25 \\
5\end{array}$ & 2.31 & 4.13 & $\begin{array}{r}3.139 \\
2\end{array}$ & .37559 \\
\hline $\begin{array}{c}\text { Stress } \\
\text { Managem } \\
\text { ent }\end{array}$ & $\begin{array}{r}25 \\
5\end{array}$ & 2.00 & 4.63 & $\begin{array}{r}3.090 \\
2\end{array}$ & .54550 \\
\hline
\end{tabular}

Questions were rated on the 5-linkert scale (strongly disagree $=1$, disagree $=2$, neutral $=3$, agree $=4$ and strongly agree $=5$ ). Minimum response for CGPA response 2.30(showing disagree) and maximum value was 3.91(representing strongly agree) and the mean value for CGPA is 3.2751 represents that tendency of responses is "Agree" and standard deviation is 0.42168 which shows less variation in the data and support the previous statement. All variables mean lies near mean values and very less dispersion in responses are shown, which means that respondents agree and confirm the effects of Socio-emotional Intelligence on academic performance.

Correlation Analysis

Table 3. Correlation Analysis

\begin{tabular}{clr}
\hline & Correlations & \multicolumn{1}{c}{ CGPA } \\
\hline CGPA & Pearson Correlation & 1 \\
Age & Pearson Correlation & $.265^{* *}$ \\
Intrapersonal & Pearson Correlation & $.501^{* *}$ \\
General Mood & Pearson Correlation & $.396^{* *}$ \\
Interpersonal & Pearson Correlation & .047 \\
Stress Management & Pearson Correlation & .096 \\
Adaptability & Pearson Correlation & $.331^{* *}$ \\
SEI & Pearson Correlation & $.398^{* *}$ \\
\hline
\end{tabular}

**. Correlation is significant at the 0.01 level (2-tailed).

All constructs were positively correlated with academic performance. In our study Age, Intrapersonal skills, General Mood, SEI Adoptability have significant relationship, while interpersonal and stress management has insignificant association with the dependent variable academic performance. Overall socioemotional intelligence (EI) are moderate positively correlated with academic performance, which shows influence of independent variable on dependent variable. Regression ANOVA table: 
Table 4; Model Summary

\begin{tabular}{|c|c|c|c|c|}
\hline $\begin{array}{l}\text { Mo } \\
\text { del }\end{array}$ & $\mathrm{R}$ & $\begin{array}{c}\mathrm{R} \\
\text { Squa } \\
\text { re }\end{array}$ & $\begin{array}{l}\text { Adjus } \\
\text { ted R } \\
\text { Squar } \\
\text { e }\end{array}$ & $\begin{array}{c}\text { Std. } \\
\text { Error of } \\
\text { the } \\
\text { Estimate }\end{array}$ \\
\hline 1 & $.398^{a}$ & .158 & .155 & .37248 \\
\hline
\end{tabular}

a. Predictors: (Constant), EI

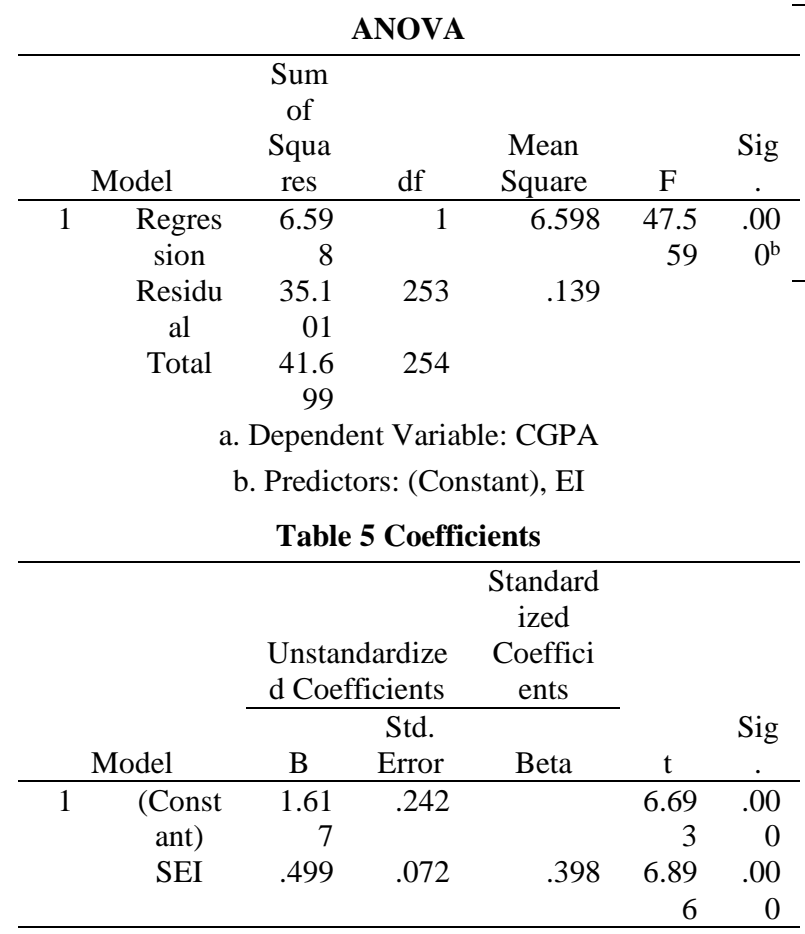

Table 4 shows the fitness of the model. Residual sum of square is 35.101 which show the unexplained deviation of dependent variable i.e. academic performance (CGPA) from its estimate. The F-statistics is 47.559 at $.000 \mathrm{sig}$ level which is less than the cutoff of 0.05. This shows significant relationship between the independent variables and dependent variable. The significance value shows that the model is fit for this study.

Table 5 shows that Socio-emotional Intelligence has a significant value (.000) which means that there is a direct and positive impact of socio-emotional intelligence on academic performance. The analysis shows that independent variable has significant impact on the dependent variable academic performance.

To see the impact of socio-emotional intelligence on academic performance on the bas basis of gender, ANNOVA was used, whose results are shown in the below table 6 . Significant difference is seen of socio- emotional intelligence on academic performance on the basis of gender on all constructs of the study. It means that impact of socio-emotional intelligence is different for male and female.

Table 6 ANOVA for Gender

\begin{tabular}{|c|c|c|c|c|c|c|}
\hline \multirow[t]{3}{*}{ CGPA } & $\begin{array}{c}\text { Between } \\
\text { Groups }\end{array}$ & $\begin{array}{c}\text { Sum of } \\
\text { Squares } \\
10.495\end{array}$ & $\begin{array}{c}\text { Df } \\
1\end{array}$ & $\begin{array}{l}\text { Mean } \\
\text { Square } \\
10.495\end{array}$ & $\begin{array}{c}\mathrm{F} \\
85.092\end{array}$ & $\begin{array}{l}\text { Sig. } \\
.000\end{array}$ \\
\hline & $\begin{array}{l}\text { Within } \\
\text { Groups }\end{array}$ & 31.204 & 253 & .123 & & \\
\hline & Total & 41.699 & 254 & & & \\
\hline \multirow[t]{3}{*}{ Intrapersonal } & $\begin{array}{c}\text { Between } \\
\text { Groups }\end{array}$ & 7.612 & 1 & 7.612 & 28.159 & .000 \\
\hline & $\begin{array}{l}\text { Within } \\
\text { Groups }\end{array}$ & 68.394 & 253 & .270 & & \\
\hline & Total & 76.007 & 254 & & & \\
\hline \multirow[t]{3}{*}{$\begin{array}{c}\text { General } \\
\text { Mood }\end{array}$} & $\begin{array}{c}\text { Between } \\
\text { Groups }\end{array}$ & 4.542 & 1 & 4.542 & 24.350 & .000 \\
\hline & $\begin{array}{l}\text { Within } \\
\text { Groups }\end{array}$ & 47.196 & 253 & .187 & & \\
\hline & Total & 51.738 & 254 & & & \\
\hline \multirow[t]{3}{*}{ Interpersonal } & $\begin{array}{c}\text { Between } \\
\text { Groups }\end{array}$ & .110 & 1 & .110 & .782 & .377 \\
\hline & $\begin{array}{l}\text { Within } \\
\text { Groups }\end{array}$ & 35.721 & 253 & .141 & & \\
\hline & Total & 35.831 & 254 & & & \\
\hline \multirow{3}{*}{$\begin{array}{c}\text { Stress } \\
\text { Management }\end{array}$} & Between & .158 & 1 & .158 & .531 & .467 \\
\hline & $\begin{array}{l}\text { Groups } \\
\text { Within } \\
\text { Groups }\end{array}$ & 75.424 & 253 & .298 & & \\
\hline & Total & 75.582 & 254 & & & \\
\hline \multirow[t]{3}{*}{ SEI } & $\begin{array}{c}\text { Between } \\
\text { Groups }\end{array}$ & 1.082 & 1 & 1.082 & 9.145 & .003 \\
\hline & $\begin{array}{l}\text { Within } \\
\text { Groups }\end{array}$ & 29.927 & 253 & .118 & & \\
\hline & Total & 31.009 & 254 & & & \\
\hline
\end{tabular}

Mean comparison table. 7 shows that female students are having more "Intrapersonal skills" (Mean=3.57), better in managing "General Mood" $(\mathrm{M}=3.88)$, and overall, they are having better socio-emotional skills $(\mathrm{M}=3.40)$ as compared to male students with Mean scores $3.22,3.61$ and 3.27 respectively. In contrast Male students are having more interpersonal skills $(\mathrm{M}=3.15)$ and better able to manage stress $(M=3.10)$ as compared to female students $(M=3.11)$ and (3.05) respectively. 


\section{Jamshid Ali Turi, et al. /Journal of Educational Administration Research and Review/Vol. 2 No. 2 December 2018}

To see the impact of socio-emotional intelligence on academic performance on the bas basis of Academic qualification, ANNOVA was used, whose results are shown in the below table 8. Significant difference is seen in the level of socio-emotional intelligence on academic performance on the basis of academic qualification on all constructs of the study. It means that impact of socio-emotional intelligence is different for the students with different qualifications.

\begin{tabular}{ccccccc}
\hline \multicolumn{7}{c}{ Tabel 8 } \\
\hline & & Intra & Gene & Interp \\
ral & erson \\
Program & perso & $\begin{array}{c}\text { Stress } \\
\text { Manag } \\
\text { of Study }\end{array}$ & $\begin{array}{c}\text { nal } \\
\text { Mood }\end{array}$ & $\begin{array}{c}\text { Socio- } \\
\text { emotional } \\
\text { Intelligen } \\
\text { ce }\end{array}$ \\
\hline BS & Me & 3.211 & 3.598 & 3.030 & 2.9523 & 3.1983 \\
& an & 8 & 6 & 5 & & \\
MS & Me & 3.532 & 3.860 & 3.276 & 3.1277 & 3.4492 \\
& an & 1 & 8 & 1 & & \\
Ph & Me & 3.457 & 3.798 & 3.193 & 3.5341 & 3.4956 \\
D & an & 1 & 0 & 2 & & \\
Tot & Me & 3.357 & 3.718 & 3.139 & 3.0902 & 3.3263 \\
al & an & 8 & 0 & 2 & & \\
\hline
\end{tabular}

Table. 7 Mean Comparison

\begin{tabular}{ccrrrrr}
\hline & & $\begin{array}{c}\text { Intrap } \\
\text { erson } \\
\text { al }\end{array}$ & $\begin{array}{c}\text { Gen } \\
\text { eral } \\
\text { Moo } \\
\text { Gender }\end{array}$ & $\begin{array}{c}\text { Interpe } \\
\text { rsonal }\end{array}$ & $\begin{array}{c}\text { Stress } \\
\text { Manage } \\
\text { ment }\end{array}$ & $\begin{array}{c}\text { Socio- } \\
\text { emotional } \\
\text { intelligence }\end{array}$ \\
\hline $\begin{array}{c}\text { Femal } \\
\text { e }\end{array}$ & Mean & 3.576 & 3.88 & 3.1129 & 3.0587 & 3.4087 \\
Male & Mean & 3.221 & 69 & & & \\
& & 3 & 25 & 3.1557 & 3.1099 & 3.2748 \\
Total & Mean & 3.357 & 3.71 & 3.1392 & 3.0902 & 3.3263 \\
& & 8 & 80 & & & \\
\hline
\end{tabular}

From the mean comparison table 9, it is shown that MS student is having more intrapersonal skills, interpersonal skills and better able to manage mood (Mean=3.53, Mean= 3.27, \& Mean=3.86) as compared to BS (Mean=3.21, Mean=3.03 \& Mean=3.59) and PhD students $($ Mean=3.45, Mean=3.19 \& Mean= 3.79) respectively. $\mathrm{PhD}$ students are having more

stress management skills and overall better socio-emotional skills (Mean $=3.53$ \& Mean $=$ 3.49) as compared to MS students (Mean $=3.12$ $\&$ Mean $=3.449)$ and BS Students (Mean=2.95 \& 3.19)

\begin{tabular}{|c|c|c|c|c|c|c|}
\hline & & $\begin{array}{l}\text { Sum of } \\
\text { Squares }\end{array}$ & $\mathrm{df}$ & $\begin{array}{c}\text { Mean } \\
\text { Square }\end{array}$ & $\mathrm{F}$ & Sig. \\
\hline \multirow[t]{5}{*}{ CGPA } & Between & 8.664 & 2 & 4.332 & 33.0 & .000 \\
\hline & Groups & & & & 46 & \\
\hline & Within & 33.035 & 252 & .131 & & \\
\hline & Groups & & & & & \\
\hline & Total & 41.699 & 254 & & & \\
\hline \multirow{5}{*}{$\begin{array}{c}\text { Intraper } \\
\text { sonal }\end{array}$} & Between & 5.879 & 2 & 2.940 & 10.5 & .000 \\
\hline & Groups & & & & 64 & \\
\hline & Within & 70.127 & 252 & .278 & & \\
\hline & Groups & & & & & \\
\hline & Total & 76.007 & 254 & & & \\
\hline \multirow{5}{*}{$\begin{array}{c}\text { General } \\
\text { Mood }\end{array}$} & Between & 3.934 & 2 & 1.967 & 10.3 & .000 \\
\hline & Groups & & & & 70 & \\
\hline & Within & 47.804 & 252 & .190 & & \\
\hline & Groups & & & & & \\
\hline & Total & 51.738 & 254 & & & \\
\hline \multirow{5}{*}{$\begin{array}{c}\text { Interper } \\
\text { sonal }\end{array}$} & Between & 3.348 & 2 & 1.674 & 12.9 & .000 \\
\hline & Groups & & & & 89 & \\
\hline & Within & 32.483 & 252 & .129 & & \\
\hline & Groups & & & & & \\
\hline & Total & 35.831 & 254 & & & \\
\hline Stress & Between & 9.122 & 2 & 4.561 & 17.2 & .000 \\
\hline \multirow{4}{*}{$\begin{array}{c}\text { Manage } \\
\text { ment }\end{array}$} & Groups & & & & 94 & \\
\hline & Within & 66.460 & 252 & .264 & & \\
\hline & Groups & & & & & \\
\hline & Total & 75.582 & 254 & & & \\
\hline \multirow[t]{5}{*}{ SEI } & Between & 4.465 & 2 & 2.233 & 21.1 & .000 \\
\hline & Groups & & & & 97 & \\
\hline & Within & 26.543 & 252 & .105 & & \\
\hline & Groups & & & & & \\
\hline & Total & 31.009 & 254 & & & \\
\hline
\end{tabular}

\section{RESULTS AND DISCUSSION}

000 This study explored the impact of socio-emotional intelligence on academic performance in the higher educational level. It is confirmed from the study's results that socio-emotional 000 intelligence has greater impact on academic performance and it plays its critical role as a moderator and mediator in different situations and enhance academic performance of the .00 learner. Although its intensity and application remain different for gender, age and level of education. Females are found to be more selffocused, having better socio-emotional and intrapersonal skill and better able to manage their moods. Males are better in managing stress and having good interpersonal skills. 000 With the increase in educational level, overall socio-emotional skill of the learner increases for both male and female. PhD students are having higher socio-emotional skills as 000 compared to $\mathrm{MS}$ and $\mathrm{BS}$ students and can betterly manage their stresses. Masters' students are found more intrapersonal, interpersonal and better to manage their moods. For undergrads' students, the values of SEI and 
all its components remained lower, which support the research findings that with the increase in educational level and age socioemotional intelligence level improve.

Studies has greater implications for learning environment and policy maker. Emotionally charged environment remains supportive and helpful for learning catching and occurring. Educational policy maker should make a part of curriculum at different level especially in teacher training programs so that we can get better productive results from the learning activities.

\section{CONCLUSION/RECOMENDATION}

Study indicates that there is a significant impact of socio-emotional intelligence on academic performance. Therefore, it is recommended that rigorous training workshops and courses regarding socio-emotional intelligence development should be included in curriculum and training. Teacher should be trained for socio-emotional intelligence so that they can better handle and predict student academic performance. Future research is recommended to explore and test socioemotional intelligence for behavior modification, EI teaching strategies and on designing evaluation studies that assess changes in knowledge (learning), behavior (expertise), and results (performance).

\section{REFERENCES}

Abdelkarim, R., \& Abuiyada, R. (2016). The Effect of Peer Teaching on Mathematics Academic Achievement of the Undergraduate Students in Oman. International Education Studies, 124-133.

Academic Skills Center. (2013). Stress management. California: California Polytechnic State University.

Ali, A., \& Saif, M. (2011). Presence and potential of emotional intelligence (EI) in organizational settings. African Journal of Business Management, 6117-6122.

Ali, I., Khan, M. A., Hamid, K., \& Afzal, H. (2010). A Study of University Students' Motivation and Its Relationship with Their Academic Performance. International Journal of Business and Management, 80-89.

Ameen, A. (2012). The introduction of activity based learning aids into undergraduate legal professional practice courses. International Conference on Engaging Pedagogy (pp. 1-20). Ireland: International Conference on Engaging Pedagogy.

Arockia, M., \& Sangeetha, R. (2013). The Relationship between Emotional Intelligence and the
Academic Performance among Final Year under Graduates. Universal Journal of Psychology, 41 45.

Bar-On, R. (2006). The Bar-On model of emotionalsocial intelligence (ESI). Psicothema , 13-25.

Baucum, N. J. (1997). The study of slow learner with special emphasis in the feild of Mathematics. Texas : Texas Technological College .

BBPSD. (2010). self-awareness and Personal development. London: British Business Professional Skills Development.

Bhadouria Preeti. (2013). Role of Emotional Intelligence for Academic Achievement for Students. Research Journal of Educational Sciences, 8-12.

Blerk, W. E. (2013). The role of emotional intelligence in implementing information technology strategies. Cape Peninsula University of Technology: USA.

Borah, R. R. (2013). Slow Learners: Role of Teachers and Guardians in Honing their Hidden Skills. International Journal of Educational Planning \& Administration, 139-143.

Boud, D., Cohen, R., \& Sampson, J. (2006). Peer learning and assessment. Assessment and Evaluation in Higher Education, 413-426.

Bratton, V. K., Dodd, N. G., \& Brown, F. W. (2011). The impact of emotional intelligence on accuracy of self-awareness and leadership performance. Leadership \& Organization Development Journal, 127 - 149.

Center for Mental Health in Schools at UCLA. (2015). Attention Problems: Intervention and Resources. Los Angeles: Center for Mental Health in Schools at UCLA.

Cestone, C. M., Levine, R. E., \& Lane, D. R. (2008). Peer assessment and evaluation in team-based learning. Wiley Periodicals, Inc.

Chamundeswari, D. S. (2013). Emotional Intelligence and Academic Achievement among Students at the Higher Secondary Level. International Journal of Academic Research in Economics and Management Sciences, 178-188.

Chaudhry, A. A., Ja, F. A., Sajjad, M., \& Ali, S. ( 2013). Emotional Intelligence and Students: A Pakistani Perspective. World Applied Sciences Journal, 319-325.

Chauhan, S. (2011). Slow learners: their psychology and educational programmes. International Journal of Multidisciplinary Research, 279-290.

Ciarrochi, J., Chan, A. Y., \& Bajgoar, J. (2001). Measuring Emotional Intelligence in Adolescents. Personality and Individaul differences, 1105-1119.

Costa, A., \& Faria, L. (2015). The impact of Emotional Intelligence on academic achievement: A longitudinal study in Portuguese secondary school. Learning and Individual Differences , 3847.

D'Amore,D. (2008). Social awareness as an indicator of self-awareness: the mead cooley model and research methodology in nonhuman primates. tenj journal of student scholarship,1-9.

Dasaradhi, K., \& Rajeswari, C. S. (2016). 30 Methods to Improve Learning Capability in Slow Learners. International journal of English language, literature and humanity, 556-570.

Dunne, M., Humphreys, S., \& Sebba, J. (2007). Effective Teaching and Learning for Pupils in Low Attaining Groups. Sussex: University of Sussex .

Durlak, J. A., Weissberg, R. P., Dymnicki, A. B., \& Schellinger, K. B. (2011). The Impact of Enhancing Students' Social and Emotional 
Learning:A Meta-Analysis of School-Based Universal Interventions. Child Development.

Eleby, C. (2009). The Impact of a Student's Lack of Social Skills on their Academic Skills in High School. Michigan: Marygrove College.

Elfenbein, H. A. (2008). Emotion in Organizations:A Review and Theoretical Integration. Berkeley: University of California.

Elfenbein, H. A., Marsh, A. A., \& Ambady, N. (2014). Emotional Intelligence and the Recognition of Emotion from Facial Expressions. Harvard University: Harvard University.

F, I., \& V, K. (2008). Empathy and emotional intelligence: What is it really about? International Journal of Caring Sciences, 118-123.

Fagan, J. F. (2000). A Theory of Intelligence as Processing. Psychology, Public Policy, and Law , 168-179.

Fayombo, G.A. (2012).Relating emotional intelligence to academic achievement among university students in Barbados. The International Journal of Emotional Education,43-54.

Febrilia, I., Warokka, A., \& Abdullah, H. H. (2011). University Students' Emotional State and Academic Performance: New Insights of Managing Complex Cognitive. Journal of eLearning and Higher Education, 1-15.

Feitosa, F. B., Prette, Z. A., \& Prette, A. D. (2012). Social skills and academic achievement: the mediating function of cognitive competence. Temas em Psicologia, 61 - 70 .

Fernández-Berrocal, P., \& Extremera, N. ( 2006). Emotional intelligence: A theoretical and empirical review of its first 15 years of history. Psicothema, 7-12.

Florez, I. R. (2011). Developing Young Children's SelfRegulation through Everyday Experiences. Reprinted from Young Children, 46-52.

FME. (2014). Understanding Emotional Intelligence. online: Free Management e-books.com.

Gardner, H. (1983). The Theory of Multiple Intelligences . Cambridge: Harvard University .

Ghabanchi, Z. (2014). The Correlation of IQ and Emotional Intelligence with Reading Comprehension. The Reading Matrix, 135-145.

Ghosh, D. S. (2014). Emotional Intelligence and Academic Achievement among Advantage and Disadvantage Children. The International Journal of Indian Psychology, 111-118.

Gill, R.(2002).Emotional intelligence and its role in organisational success. Training Journal, 1-8.

Goleman, D. (1995). Daniel Goleman's emotional intelligence: why it can matter more than iq.

Goroshit, M., \& Hen, M. (2012). Emotional Intelligence: A Stable Change?. International Journal of Teaching and Learning in Higher Education , 3142 .

granham, s., \& Weiner, B. (2001). Theories and Principles of Motivations. National Science Foundation, 63-85.

Gumora, G., \& Arsenio, W. F. (2002). Emotionality, Emotion Regulation, and School Performance in Middle School Children. Journal of School Psychology, 395 - 413.

Hariharan, P. (2011). Effectiveness of Activity - Based - Learning Methodology for Elementary School Education. India: Coimbatore.

Hen, M., \& Goroshit, M. (2014). Academic Procrastination, Emotional Intelligence, Academic Self-Efficacy, and GPA: A Comparison Between Students With and Without Learning Disabilities. Journal of Learning Disabilities.
Hojat, M., Gonnella, J. S., \& Mangione, S. ( 2002). Empathy in medical students as related to academic performance, clinical competence and gender. Medical Education, 522-527.

Holtkamp, M. (2014). Leadership skills and the role of adaptability and creativity in effective leadership: A literature review geared toward an integrative model. 3rd IBA Bachelor Thesis Conference (pp. 1-9). The Netherlands: University of Twente, Faculty of Management and Governance.

Huitt, W. G., \& Dawson, C. (2011). Social Development: Why It Is Important and How To Impact It. Valdosta : Valdosta State University.

Jordan, P. J. (2014). Emotional intelligence: The role of emotion in the workplace. Australia: Griffith Business School.

Khan, M., Muhammad, N., Ahmed, M., Saeed, F., \& Khan, S. A. (2012). Impact of activity-based teaching on students' academic achievements in physics at secondary level. Academic Research International, 146-157.

Khosravi, B. G., Manafi, M., Hajobri, R., Aghapour, A. H., \& Ghashani, R. (2011). The Relationship between Emotional Intelligence and Effective Delegation. International Journal of Business and Social Science, 223-236.

Khurshid, S., Parveen, Q., Yousuf, M. I., \& Chaudhry, A. G. (2015). Effects of depression on students' academic performance. Pakistan Association of Anthropology, Islamabad, Pakistan, 119-125.

Kitsantas, A., Winsler, A., \& Huie, F. (2008). SelfRegulation and Ability Predictors of Academic Success During College: A Predictive Validity Study. Journal of Advanced Academics, 42-68.

Klinic Community Health Centre. (2010). Stress \& Stress Management. Canada: Klinic Community Health Centre.

Kranner, I., Minibayeva, F. V., Beckett, R. P., \& Sea, C. E. (2010). What is stress? Concepts, definitions and applications in seed science. New Phytologist Trust, 655-674.

Langford, J., Smola, A. J., \& Zinkevich, M. (2009). Slow Learners are Fast. Australia: Labs and Australian National University.

Levin, H. M. (2012). The Importance of Educational Adaptability. Columbia: Teachers College, Columbia University.

Lo, M. L. (2012). Variation Theory and the Improvement of Teaching and Learning. Göteborg: Acta Universitatis Gothoburgensis.

Loise M.Ladrazo, A. C., \& Barchard, K. A. (2013). How is Emotional Intelligence Related to Academic Performance? Las Vegas: University of Nevada.

Luthans, F. (2011). Organizational Behavior. McGrawHill.

Lynch, S. A., \& Simpson, C. G. (2010). Social Skills:Laying the Foundation for Success. DIMENSIONS OF EARLY CHILDHOOD, 212.

Macleod, F., \& Golby, M. ( 2003 ). Theories of Learning and Pedagogy: issues for teacher development. Teacher Development, 345-363.

Malik, N. I., \& Hanif, G. R. (2012). Effect of Academic Interventions on the Developmental Skills of Slow Learners. Pakistan Journal of Psychological Research, 135-151.

Mandale, P. (2010). Impact of Stress Management on Learning in a Classroom Setting. Kentucky : Western Kentucky University.

Maria A. Polak, A. C., Flet, J. A., Brookie, K. L., \& S.Conner, T. (2015). Measuring Mood: Considerations and Innovations for Nutrition 

Science. London: Department of
Psychology,University of Otago.

Matuga, J. M. (2009). Self-Regulation, Goal Orientation, and Academic Achievement of Secondary Students in Online University courses. Educational Technology \& Society, 4-12.

Mayer, \& Ciarrochi. (2006). Emotional Intelligence in everyday life.

Mayer, J. D., Salovey, P., Caruso, D. R., \& Cherkasskiy, L. (2011). Emotional Intelligence.

Miller, H. (2009). Adaptable Spaces and Their Impact on Learning Research Summary.

Morin, A. (2011). Self-Awareness Part 1: Definition, Measures, Effects, Functions, and Antecedents. Social and Personality Psychology Compass, 807-823.

Morrison, F. J., Ponitz, C. C., \& McClelland, M. M. (2010). Self-regulation and academic achievement in the transition to school. Washington: University of Michigan, Department of Psychology.

Muhammad, A. S., Bakar, N. A., Mijinyawa, S. I., \& Halabi, K. A. (2014). impact of motivation on students' academic performance: a case study of university sultan zainal abidin students. The American Journal of Innovative Research and Applied Sciences, 222-228.

N, V., \& Shastri, S. (2016). Stress and Academic Performance. The International Journal of Indian Psychology , 70-82.

Nasir, M. (2012). Effects of Cultural Adjustment on Academic Achievement of International Students. Journal of Elementary Education, 95103.

Nasir, M., \& Masrur, R. (2010). An Exploration of Emotional Intelligence of the Students of IIUI in Relation to Gender Age and Academic Achievement. Bulletin of Education and Research, 37-51.

Northern Illinois University. (2005). Howard Gardner's Theory of Multiple Intelligences. Cambridge: Faculty Development and Instructional Design Center.

Notman, R. (2012). Intrapersonal factors in New Zealand school leadership success. International Journal of Educational Management, 470 - 479.

Okpara, A., \& Edwin, A. M. (2015). self awareness and organizational performance in the nigerian banking sector. European Journal of Research and Reflection in Management Sciences, 53-71.

Oliver, T. (2014). Conceptualizing and Assessing Interpersonal Adaptability: Towards a Functional Framework. Belgium: Ghent University, Belgium.

Omomia, T. A., Omomia, O. A., Chimezie, C. U., \& Akinwale, G. (2014). Perceived Impact of Stress on the Academic Achievement of Biology Students in Education District IV, Lagos State. Nigeria. European Journal of Psychological Studies, 85-93.

Pal, H., Pal, A., \& Tourani, P. (2004). Theories of Intelligence. Everyman's Science, 181-193.

Palmer, B., Walls, M., Burgess, Z., \& Stough, C. (2001). Emotional intelligence and effective leadership. Leadership \& Organization Development Journal, 5-10.

Peklaj, C., \& Levpušček, M. P. (n.d.). Students' motivation and academic success in relation to the quality of individual and collaborative work during a course in educational psychology. Association of Teacher Education in Europe 3rd annual conference (pp. 147-162). Europe: Association of Teacher Education in Europe .
Pentland, B. T., \& S.Feldman, M. (2005). Organizational Routine as a unit of analysis. Industerial and corporate change, 793-815.

Petrides, K., Federickson, N., \& Furnham, a. (2004). The role of trait emotional intelligence in academic performance and deviant behavior at school. Personality and Individual Differences, 277-193.

Polgar, S. (2011). Intelligence :My Brilliant Brain. london: oxford.

Polk, D. M. (2013). Cultivating Self-Awareness with Team-Teaching: Connections between Classroom Learning and Experiential Learning. Journal of Leadership Education, 122-134.

Prakash, J., \& M, V. (2015). Self-awareness and Selfmotivation Has Stimulus on the Academic Concert of XI Standard Pupils in Biology Subject. International Journal of Scientific Engineering and Applied Science, 93-100.

Pujar, L. L. (2006). Instructional strategies to accelerate science learning among slow learners. Dharwad : University of agricultural sciences.

Pulakos, E. D., \& Arad, S. (2001). Adaptability in the Workplace: Development of a Taxonomy of Adaptive Performance. USA: University of Illinois at Urbana-Champaign.

Raja, W. D., \& Selvi, K. ( 2011). Causes of problems in learning english as a second language as perceived by higher secondary students. imanager's Journal on English Language Teaching, 40-46.

Rajasekar. (2013). Impact of academic stress among the management students of amet university - an analysis. AMET International Journal of Management, 32-41.

Reader, M. (2012). Setting Students up for Success Through Self-Awareness and Self-Advocacy. PERSPECTIVES.

Reigeluth, C. M. (2012). Instructional Theory and Technology for the New Paradigm of Education. Revista de Educación a Distancia, 31-49.

Riemer, M. (2003). Integrating emotional intelligence into engineering education. World Transactions on Engineering and Technology Education, 189195.

Robbins, S. P. (1996). Organizational Behavior . Boston : San Diego State University.

Ruhela, R. ( 2014 ). The Pain of the Slow Learners Online International Interdisciplinary Research Journal, 193-200.

S, N., Jose, T. T., \& Valsaraj, B. P. (2015). Effectiveness of academic stress management programme on academic stress and academic performance among higher secondary students in selected schools of Udupi District. Nitte University Journal of Health Science, 9-13.

Salovey, P. (1999). Emotional Intelligence and the coping process. New York: Oxford Universty press.

Sambaiah, A. (2016). Intra personal skills as core of the personality: some home truths. Journal of english language and literature, 225-231.

Shabana, \& Begum, K. (2013). To study the difference in academic achievement of higher secondary school students on the basis of emotional intelligence. Elixir Psychology , 96-99.

Shaw, S. (2013). 7 Strategies for Highly Effective Support for students with MID and slow learners. Ottawa Catholic school board.

Shaw, S. R. (2010). Rescuing Students From the Slow Learner Trap. National Association for secondary school principals. 


\section{December 2018}

shaw, S. R. (2013). Slow learner and mental health problems: Over-presented and overlooked. National association of school psychologists.

Shipley, N. L., Jackson, M. J., \& Segrest, S. L. (2003). The effects of emotional intelligence, age, work experience, and academic performance. Research in Higher Education Journal .

Singh, K. (2011). Study of Achievement Motivation in Relation to Academic Achievement of Students. International Journal of Educational Planning \& Administration, 161-171.

Solak, E. (2012). Exploring the Role of Motivational Factors in the Academic Achievement of EFL Learners. International Association of Research in Foreign Language Education and Applied Linguistics, 240-254.

Suranjana, R., Ujjani, R., \& Kanti, R. M. (2015). Peer Tutoring as a Remedial Measure for Slow Learners in a Medical School. Journal of Krishna Institute of Medical Sciences University, 130135.

Taheri, L. (2016). The Relationship between Emotional Intelligence and Learning Strategies among Iranian EFL. Theory and Practice in Language Studies, 952-957.

Tariq, R., Sohail, \& Aslam, M. (2011). Impact of Employee Adaptability to Change Towards Organizational Competitive Advantage. Double Blind Peer Reviewed International Research Journa, 9-18.

Tella, A. ( 2007). The Impact of Motivation on Student's Academic Achievement and Learning Outcomes in Mathematics among Secondary School Students in Nigeria. Eurasia Journal of Mathematics, Science \& Technology Education, 149-156.

The McGraw-Hill Companies. (2010). Understanding Behavior, Human Relations, and Performance. USA: The McGraw-Hill Companies.

Thomson, N. (2012). Language teaching strategies and techniques used to support students learning in a language other than their mother tounge. Norway: Kongsberg International School.
Tiwari, R., Pandey, M., \& Sharma, A. (2010). An Approach to Human Adaptability towards its Built Environment: A Review. Energy and Power Engineering, 90-94.

Topping, K. J. (2005). Trends in Peer Learning. Educational Psychology, 631-645.

Totawar, A. K., \& Nambudiri, R. (2013). Mood and SelfEfficacy: The Moderation of Hedonic and Utilitarian Motivation. Human Resource Development Review.

UNESCO. (2005). Guidelines for Inclusion: Ensuring access to education for all. France: UNESCO.

University of Oslo. (2008). English Classroom Interaction between Slow Learners and Teachers. Norway: University of Oslo .

Urdang, E. (2010). Awareness of Self-A Critical Tool. Social Work Education, 523-538.

Yahaya, A., Sar, N., Yahaya, N., Boon, Y., Hashim, S., \& G. M. (2012). The Impact of Emotional Intelligence Element on Academic Achievement. Archives Des Sciences, 1-16.

Yahaya, A., Yahaya, N., Bon, A. T., \& Ismail2, S. ( 2011). The relationship of dimensions of emotional intelligence and academic performance in secondary school students . Elixir Psychology , 5821-5826.

Yalcin-Tilfarlioglu, F., \& Arikan, A. ( 2012). Empathy levels and academic achievement of foreign language learners. Procedia - Social and Behavioral Sciences 46, 4428 - 4430.

Zain, A. M., \& Hassan, F. (2013). Emotional intelligence and academic performance in first and final year medical students: a cross-sectional study. BMC Medical Education.

Zumbrunn, S., \& Tadlock, J. (2011). Encouraging SelfRegulated Learning in Classroom:A Review of the Literature. Virginia: Virginia Commonwealth University. 